\title{
Structural and mineragenetic features of the Getkan area
}

\author{
Yury Manilov ${ }^{1^{*}}$ \\ ${ }^{1}$ Kosygin Institute of Tectonics and Geophysics, Far East Branch, Russian Academy of Sciences, \\ Laboratory of regional geophysics and petrophysics, Khabarovsk, 680000 Russia
}

\begin{abstract}
Annotation. Deep structural features of tectonic and mineragenetic zones of the region have been established based on the comprehensive analysis of geological, gravity, magnetic, and petrophysical data. Geophysical methods that are based on different physical principles have been shown to reflect different characteristics of lithosphere. Considering structural features and physical characteristics of mineragenetic objects, the obtained data allow genesis of endogenous mineralization of different types were identified and new approaches to the forecasting process was developed.

Key words: geological information, tectonics, geophysical section, mineragenetic zone, disjunctive structure, structural block model
\end{abstract}

\section{Introduction}

Map sheet N-51-XI, scale 1: 200000 covers the study area. The geological structure (Fig. 1) and evolution of the territory under consideration reflect the influence of three large structures [1]: the Stanovoy and West Stanovoy fold-block systems (SFBS and WSFBS) and the Dzheltulak suture zone separating (stitching) them.

According to the scheme of mineragenetic zone distribution in the Baikal-Amur railway area and the mineragenetic map of the Amur Region [2,3], about $90 \%$ of the study area is part of the Stanovoy province and encompasses parts of the Yuzhnostanovoy ironmolybdenum-silver-gold ore, Dzheltulak molybdenum-iron-tungsten-gold ore, and Prishilka rare metal-copper-molybdenum-gold ore mineragenetic zones (MZ) in.

There are many gaps in present-day understanding of the geology and deep structure of the territory, as well as the character of mineragenetic zone distribution. This is due to the relative deficiency of geological and geophysical data, on the one hand, and the fact that most of the area is buried under sedimentary and volcanic rocks of varying age and composition, on the other. Boundaries between the main structural elements and mineragenetic zones are also rather controversial and are quite a matter of convention.

*Corresponding authors: ymanilov@yandex.ru 


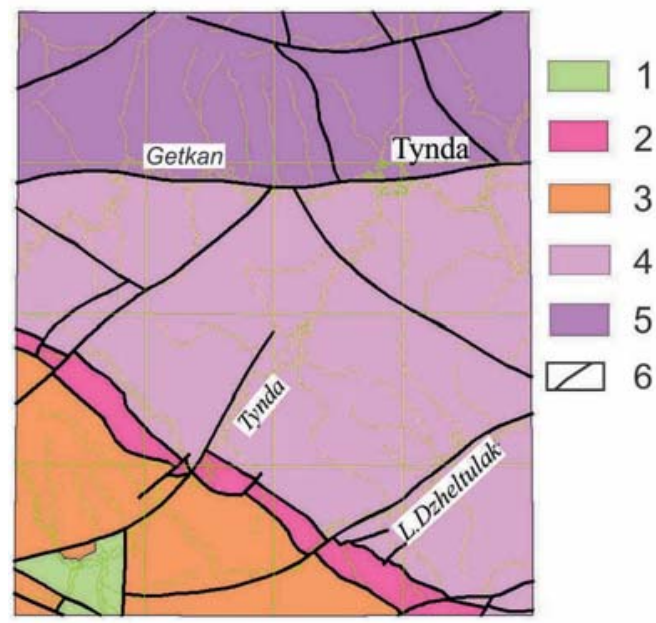

Fig. 1. Simplified tectonic map 1- Verkhnetynda superimposed basin; 2- Dzheltulak suture zone; West Stanvoy fold-block systema: 3 - Ust'-Gilyui zone; Stanovoy fold-block system: 4- Ilikan zone, 5- Larba zone; 6 - faults

This study is intended to solve some of the uncertainties. Geophysical information was invoked for a clearer understanding of the relation between geological structure and minerageny.

\section{Basic materials}

Bouguer gravity map with intermediate layer density of $2.67 \mathrm{~g} / \mathrm{cm}^{3}$, scale 1: 200000 ; contour map of the magnetic field $(\Delta \mathrm{T})_{\mathrm{a}}$, scale 1: 200000 ; geological and geophysical sections based on deep seismic sounding data, tectonic and geological maps of scales 1:200 $000-1: 1000000$, the table of physical properties of rocks in the region [4].

\section{Methodology}

The study was carried out on the basis of qualitative and quantitative interpretation of gravity, magnetic, geological, and petrophysical information.

The work was performed in two directions: underground and areal surveying, with each direction divided into two stages. At the first stage, data acquired by different techniques were processed separately, and at the second stage, simultaneous analysis of the results for different geophysical techniques was performed and compared with the geological and petrophysical data.

The main tool for geopotential field data processing was the computer technology "COSKAD 3D", intended for the analysis of 3D digital geoinformation by applying probabilistic and statistical methods [5]. The functionality of the "COSKAD 3D" complex makes it possible to carry out spectral-correlation and statistical analysis of geodata and to perform 3D modeling of gravity and magnetic responses.

\section{Results}

As a result of underground surveying, a geological and geophysical section has been generated (Fig. 2) across of the strike of the major geological structures and the orientation of anomalous fields in the area (Fig. 3). 
The areal distribution of structures has been mapped based on the schematic map of integrated interpretation of geophysical data with elements of minerageny (Fig. 3), which is the result of simultaneous analysis of gravimetry, magnetic, geological, and petrophysical data.

A priori geological-structural model of the geological section along the given profile and petrophysical parameters of its compositional complexes served as a geological basis for the interpretation model.

The Dzheltulak suture zone has the most complicated field structure, which is due to an ensemble of metamorphic and intrusive complexes of different age, which outcrop along the Dzheltulak fault system (Fig. 2).

Dislocations that determine the general direction of the main system are cut by fractures across the strike of the suture zone, which results in a complex honeycomb structure of the fault itself. Another important benchmark for the zone is high-intensity positive linear $\Delta \mathrm{T}_{\mathrm{a}}$ anomalies (over $500 \mathrm{nT}$ ), which are probably associated with intrusive magmatism along the Dzheltulak fault system.

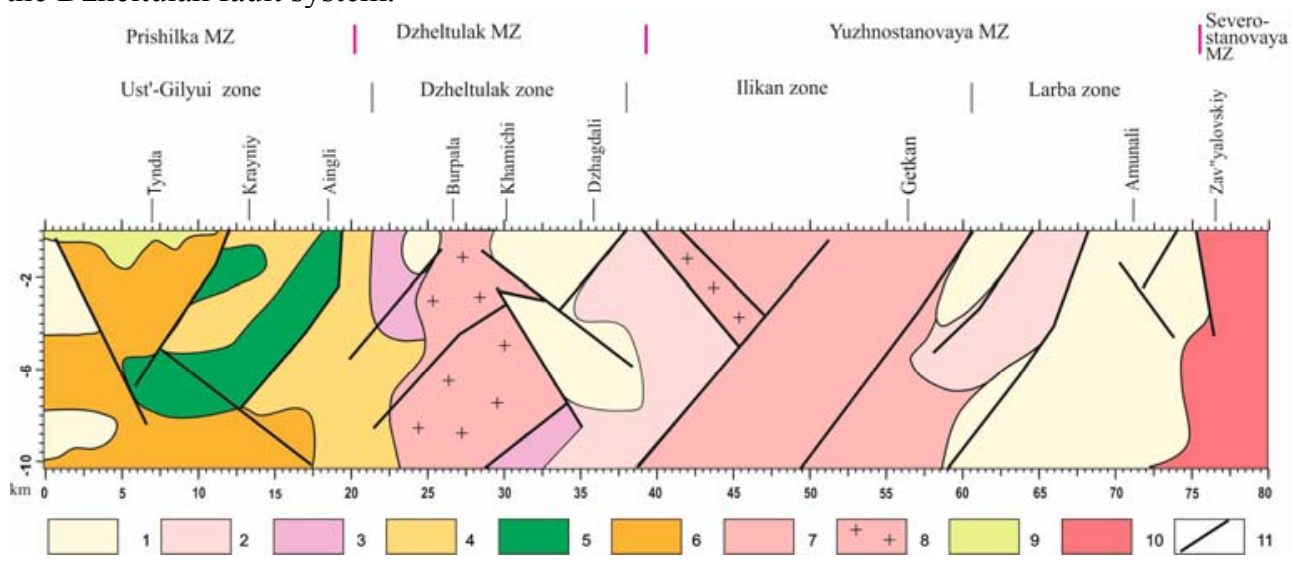

Fig. 2. Structural block model along the line $\mathrm{A}_{1}-\mathrm{A}_{2}$

The assumed nature of the blocks: 1 - Archean gneisses and crystal schists; $2-\mathrm{AR}_{2}$ granitoids; $3-\mathrm{PR}_{1}$ metamorphic rocks; 4 - Late Paleozoic - Early Mesozoic intrusions of the Nerchugan Complex; 5early Mesozoic gabbroids; 6 - Late Jurassic felsic intrusions of the Amudzhikan Complex; 7 moderately Jurassic alkaline granitoids. 8 - s Jurassic ilicified granitoids; 9 - Cretaceous granitoids; 10 - Cretaceous terrigenous deposits of the Nizhnetynda basin, 11 - faults

The structure of the Ust'-Gilyui zone (UGZ) is comprised of 3 blocks: southwest, central, and southeast. The southwest block is traceable by the strong positive field $\Delta \mathrm{T}_{\mathrm{a}}$ (over $500 \mathrm{nT}$ ) and negative field of the low intensity local component $\Delta \mathrm{g}$ (up to $10 \mathrm{mGal}$ ) and is infilled by Late Paleozoic intrusions of the Nerchugan Complex. The central block extends along the Tynda River; a domain of the weakly positive and linear field of the local component $\Delta \mathrm{g}$. The block is almost completely covered by terrigenous sediments of the Nizhnetynda basin. The suggested nature of the central block is plagiogranites of the Drevnestanovoy Complex and reworked remnants of metamorphic rocks $\mathrm{PR}_{1}-\mathrm{AR}_{2}$, which slightly increase the block density compared to the less dense and younger granitoid intrusions. The southeast block is characterized by a moderately negative field $\Delta \mathrm{T}_{\mathrm{a}}$ and a large minimum, which probably corresponds to the melting chamber of Late Jurassic acid igneous rocks, and is infilled by moderately alkaline granites of the Verkhneurkan Complex. 


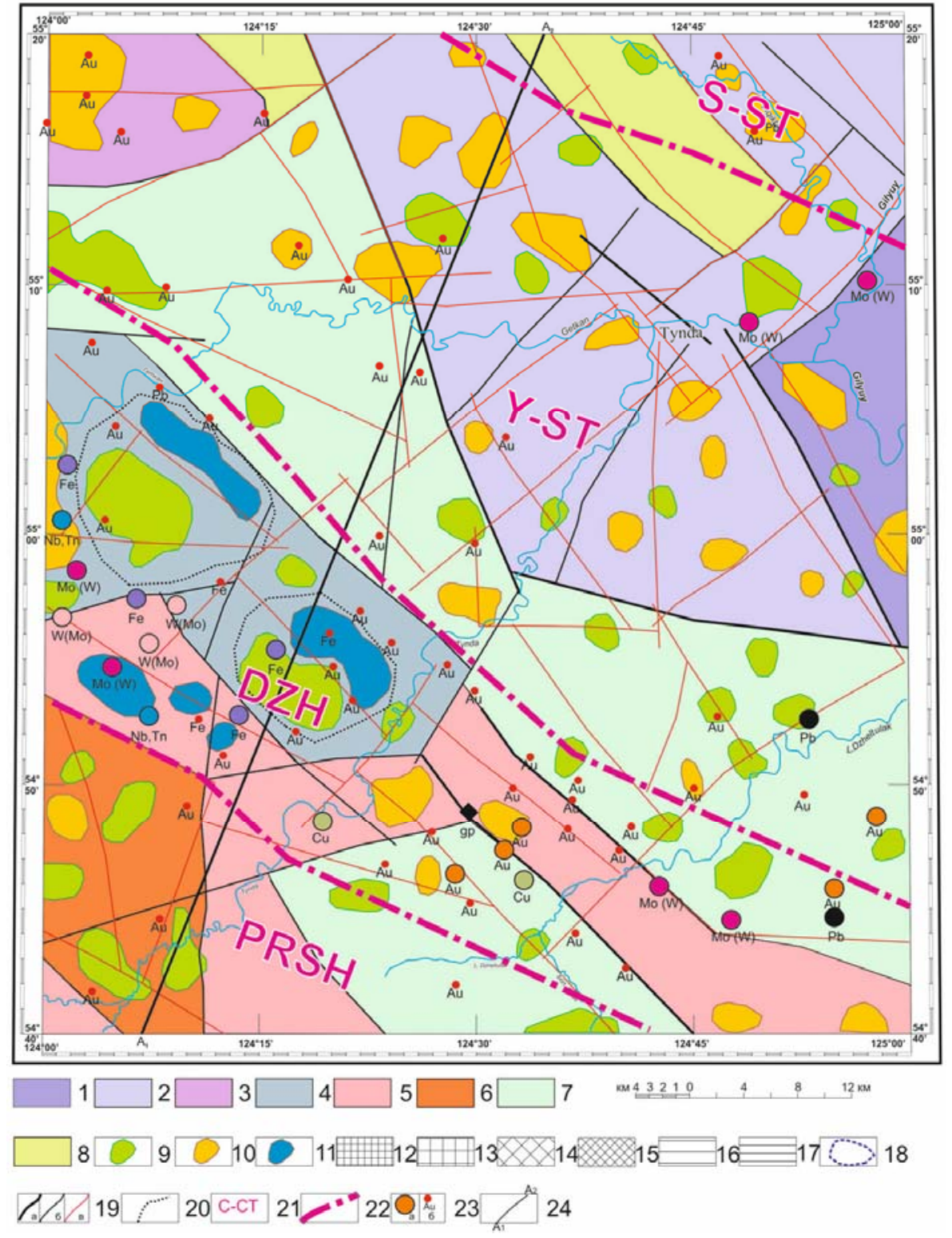

Fig. 3. Schematic map of geophysical data integrated interpretation with elements of minerageny

Interpretation of the field $\boldsymbol{\Delta} \boldsymbol{g} 1$ - the central part of the regional positive anomaly $\Delta \mathrm{g}$ of up to 30 $35 \mathrm{mGal}$, which is presumably the intact core of the ancient block represented by Archean gneisses and schists; 2- the peripheral part of the regional positive anomaly $\Delta \mathrm{g}$ of 15-20 mGal, composed of $\mathrm{AR}_{2}$ metamorphic complexes, which are intruded by intermediate to felsic intrusions of varying age; 3 - the block causes a large isometric anomaly $\Delta \mathrm{g}$ of $15-20 \mathrm{mGal}$ and is infilled by metamorphic sequences and gabbroids $\mathrm{AR}_{2} ; 4$ - domain of alternating (mostly negative) gravity field, represented by granites and metamorphites $\mathrm{AR}_{2} ; 5$ - domain of the linear positive field of the local component $\Delta \mathrm{g}$, mainly represented by metamorphites and plagiogranites $\mathrm{PR}_{1}-\mathrm{AR}_{2} ; 6$ - block of the negative field of the local component $\Delta \mathrm{g}$ of low intensity (up to $10 \mathrm{mGal}$ ), infilled by Late Paleozoic intrusions of the Nerchugan Complex; 7- domains of negative regional field $\Delta \mathrm{g}$ of high intensity (up to 25-30 mGal), which correspond to moderately alkaline Jurassic granitoids; 8 - block of the negative field of the local component $\Delta \mathrm{g}$ against the positive regional maximum, probably corresponds to the chamber of the Cretaceous granitoid magmatism; Local field anomalies $\Delta g$ : 9 - negative, associated with 
Mesozoic aged acid intrusive bodies occurring at a depth of 5-7 km; 10- positive, associated with unaltered Precambrian metamorphites; 11- positive, corresponding to the bodies of the early Mesozoic gabbroids;

Interpretation of the field $\Delta T 12$ - intense positive field (over $700 \mathrm{nT}$ ); 13- moderately positive field (up to 300-350 nT; 14- weakly differentiated alternating field $(-150-+200 \mathrm{nT}) ; 15$ - highly differentiated alternating field (-400 - +700 nT); 16- weak negative field (-200 - $0 \mathrm{nT}) ; 17$ - intense negative field (less than $-300 \mathrm{nT}$ ); Local field anomalies $\Delta T$ : 18- positive, intense (over $500 \mathrm{nT}$ ), probably associated with zones of magmatism ; Disjunctive tectonics 19- Correlation lines of gradient zones, changes in the structure of potential fields identified with the boundaries of blocks of the Earth's crust (deep fault zones): a - regional, identified by the field $\Delta \mathrm{g}, \mathrm{b}$ - lower order faults identified by the field $\Delta \mathrm{g}, \mathrm{c}$ - identified by the field $\Delta \mathrm{T} ; 20$ - radial gradients of the field $\Delta \mathrm{g}$, presumably the boundaries of ring intrusive structures; Mineragenetic elements 21- zones [2] : S-ST - Severostanovoy, Y-ST - Yuzhnstanovoy, DZH - Dzheltulak; PRSH - Prishilka; 22- boundaries of mineragenetic zones; 23 - mineragenic objects and their specialization: a- small deposits and occurrences, b- mineralization points. 24- geological and geophysical section $\mathrm{A}_{1}-\mathrm{A}_{2}$

The SFBS is the largest in terms of area and by its contrasting signatures in the fields and is clearly divided into the regional positive maximum $\Delta \mathrm{g}$ and $\Delta \mathrm{T}_{\mathrm{a}}$ of an isometric shape centered at the confluence of the Tynda and Getkan rivers near the town of Tynda and the less intense part with NNW-trending anomalies of the field. Obviously, the regional positive $\Delta \mathrm{g}$ anomaly is caused by the ancient metamorphic complexes of the Larba zone (LZ), whose age is $\mathrm{AR}_{1}-\mathrm{AR}_{2}$. Within the anomaly, the highest intensity part of the neartriangular shape is distinguished; this is probably the unaffected core of the ancient block, represented by gneisses and crystalline schists. The rest of the anomaly is of low amplitude, which is due to the fact that on the periphery, metamorphic complexes have been intruded by felsic to intermediate intrusions of varying age (from $A_{2}$ to $K_{1}$ ). The $K_{1}$ magmatism center is located in the Shakhtaum River basin. It is mapped by lower values of $\Delta \mathrm{g}$ and $\Delta \mathrm{Ta}$, and appears as a separate block in the interpretation schematic map.

Two regional minima are distinguished in the field of the rest of the SFBS: in the northwest and in the southeast, which are probably associated with the centers of Late Jurassic granitoid magmatism.

The block in the northwestmost part of the map sheet causes a large isometric anomaly $\Delta \mathrm{g}$ of 15-20 mGal; on the surface; it corresponds to the $\mathrm{AR}_{2}$ weakly altered metamorphic complexes. The high intensity of the anomaly may also be associated with $\mathrm{AR}_{2}$ gabbroids, which are mapped at the boundary with map sheet N-51-X.

According structural block model (Fig.2), local anomalies on the interpretation schematic map are caused mainly by near-surface objects at a depth of 3-5 km. Most of the positive anomalies are associated with lenses of weekly altered Precambrian metamorphic rocks. Some of the local positive anomalies correspond to basites of the Getkan Complex. Negative local anomalies are apparently caused by felsic intrusive bodies of Mesozoic age.

Two minor structures with a radial-circular shape of gradient zones of the fields $\Delta \mathrm{g}$ and $\Delta \mathrm{T}_{\mathrm{a}}$ and the radial arrangement of local anomalies have been were identified within the map sheet. Each of them is represented by 2 local anomalies: positive and negative. The nature of these structures is clearly magmatic.

\section{Minerageny}

At the current level of knowledge, the Dzheltulak $\mathrm{MZ}$ is recognized as having good potential gold, tungsten, iron, molybdenum, and graphite. Au-Mo mineralization is confined to the Yuzhnostanovoy MZ. Mineral occurrences are characteristically absent in the Prishilka and Severostanovoy MZ within the map sheet under consideration. There are 
few points of mineralization with gold. Among the points of mineralization, there are few with specialization for $\mathrm{Au}$.

The available data on mineralization of the Dzheltulak MZ are insufficient to identify areas indicating potential for being classified as ore clusters, but the geophysical information thanks to geophysical information offers a means of seeing the character of relationships between the deep structure, geology and the location of ore targets.

Most of the known targets are located along the faults, at the junction of blocks with different geological history, different physical characteristics and different composition. The constructed structural-block model shows clearly specific features of the structure at depth. The model demonstrates structural differences between tectonic and mineragenetic elements (Fig.2).

Formation processes of minerals and the main patterns in their distribution are determined by the multistage geological development. Mineragenetic epochs (ME) correspond to its individual stages - Late Archean, Early Proterozoic, Late Paleozoic-Late Jurassic, Mesozoic, and Cenozoic. Two mineragentic stages (MS), that is, Late Jurassic and Cretaceous, are recognized in the Mesozoic ME. Minerageny in the region is characterized by the multistage development of mineralization with younger epochs superimposed on the deposited mineralization resulting in regeneration of, possibly repeated, mineralization within the distinguished taxa of different ages.

Accumulation of volcano-sedimentary rocks of the Ilikan metamorphic complex, which exhibit specialization for graphite and iron, is associated with the Late Archean epoch of the crystalline basement formation. As a result of regional metamorphism, ultrametamorphism and granitization, magnetite quartzites and graphite-bearing gneisses and shales are associated with the formation of amphibolite-gneiss and quartzite-gneiss assemblages of the Ilikan and Ust'-Gilyui zones.

The Early Proterozoic stage was associated with the formation of the Dzheltulak deep fault zone (suture zone) and other NW-trending ore-controlling faults. Within the Dzheltulak MZ, the Early Proterozoic stage of intensification was associated with shearing, mylonitization, retrograde metamorphism, and metasomatism with the formation of metasomatic rocks of diverse composition. The formation of a complex of various minerals is associated with different types of metasomatic rocks.

Siliceous metasomatism is associated with the formation of the regenerated iron ore mineralization hosted by banded iron formations of the Ilikan and Ust'-Gilyui zones.

Late Paleozoic to Late Jurassic magmatism within the Prishilka rare-metal-coppermolybdenum-gold MZ predetermined the formation of copper occurrences and gold placers.

Geophysical factors also play an important role in the localization of some of the minerals. Positive magnetic anomalies within the Dzheltulak MZ are restricted to the largest bodies of magnetite quartzite.

Granite outcrops of the Kurbatov Complex are characterized by lower values of the aeromagnetic field intensity relative to granitoids of the Tynda-Bakaran Complex, which are developed to the northeast and have no mineragenetic specialization.

As of today, the study area indicates the potential for tungsten, gold, iron, and graphite. The area may be of some interest in terms of tantalum-niobate.

The study was performed as part of the State Assignment to the ITIG FEB RAS and was financially supported by the Russian Science Foundation, project no. 16-17-00015. 


\section{References}

1. A.S. Volsky, G.A. Shatkov, L.I. Krasny et al., Tectonics, deep structure and minerageny of the Amur region and adjacent areas. - SPb.: VSEGEI Publishing House (2004)

2.Yu.V. Bogdanov, Metallogenic Map of the BAM Region. Scale 1: 500 000, L. (1981)

3. A.I. Lobov, A.S. Brazhnikov et al., Comprehensive predictive and mineragenetic studies of the Amur Region on a scale of 1: 500000 (report on the GMK-500 prospect for 1991 1996). - Khabarovsk: Taezhnaya GE. 2913 p., 354F. //I ATGF-25790 (1996)

4. Physical properties of rocks of the Far East of Russia. Handbook in 2 parts. Vladivostok, Far East Branch, USSR Academy of Sciences (1987)

5. A.A. Nikitin, A.V. Petrov Theoretical foundations of geophysical data processing/M:

Center for Information Technologies in Nature Management (2010) 